LIAMES 18(2): 229-252 - Campinas, Jul./Dez. - 2018

\author{
Núbia Ferreira Rech \\ Universidade Federal de Santa Catarina, Brasil \\ http://orcid.org/0000-0002-9278-2702 \\ Ana Paula Brandão \\ Universidade Federal do Pará, Brasil \\ http://orcid.org/0000-0002-1635-9929 \\ Marina Wit \\ Universidade Federal de Santa Catarina, Brasil \\ http://orcid.org/0000-0001-8312-4217
}

\title{
The relationship between irrealis mood and deontic modality in Paresi (Arawak)
}

\begin{abstract}
This article presents a description and analysis of the deontic modality and its relationship with mood category (realis vs irrealis) in Paresi, a language of the Arawak family, spoken in Brazil. Data were collected from two questionnaires on deontics and texts. For the analysis of the data, we used, as the theoretical framework on mood and modality, the works of Feldman (1986), Hacquard (2006, 2010); Mithun $(1995,1999)$ and Palmer (2001). First, we show how the realis/irrealis mood marking occurs in Paresi. In the sequence, we describe the Paresi as a language that lexically marks the type of modality, but not the modal force. We present two markers of deontic modality in this language: maika and wa(iye)hena, which indicate both necessity and possibility. These markers exhibit particle properties and occupy high positions in the sentence structure. Finally, we describe the deontic modality of necessity, showing that there are two types of obligations in Paresi: one indicated by the maika particle; and another, by the particle wa(iye)hena. The first figures, preferably, in contexts in which a participant is directly responsible for the realization of the event and seems to be associated to the realis mood. On the other hand, wa(iye)hena is employed in contexts of laws and general rules, which describe how a state of affairs should be, and co-occurs, predominantly, with the irrealis marker.
\end{abstract}

KEYWORDS: Paresi; Irrealis; Deontic modality.

RESUMO: Este artigo apresenta uma descrição e análise da modalidade deôntica e sua relação com a categoria de modo (realis vs irrealis) em Paresi, uma língua da família Aruák, falada no Brasil. Os dados foram retirados de dois questionários sobre deônticos e de textos. Para a análise dos dados, utilizamos como aporte teórico sobre modo e modalidade os trabalhos de Feldman (1986), Hacquard (2006, 2010); Mithun $(1995,1999)$ e Palmer (2001). Primeiro, mostramos como ocorre a marcação de modo realis/irrealis em Paresi. Na sequência, descrevemos o Paresi como uma língua que marca lexicalmente o tipo de modalidade, mas não a força modal. Apresentamos duas marcas de modalidade deôntica nessa língua: maika e wa(iye)hena, que indicam tanto necessidade quanto possibilidade. Essas marcas apresentam propriedades de partícula e ocupam posições altas na estrutura da sentença. Por fim, descrevemos a modalidade deôntica de necessidade, mostrando que há dois tipos de obrigação em Paresi: uma indicada pela partícula maika; e outra, pela partícula wa(iye)hena. A primeira 
figura, preferencialmente, em contextos nos quais um participante é responsabilizado diretamente pela realização do evento e parece estar associada ao modo realis. Já wa(iye)hena é empregada em contextos de leis e regras gerais, que descrevem como um estado de coisas deve ser, e coocorre, predominantemente, com o morfema irrealis iya.

PALAVRAS-CHAVE: Paresi; Irrealis; Modalidade deôntica.

\section{Introduction}

Paresi is a language of the Arawak family, spoken in the State of Mato Grosso, Brazil, by approximately 3000 people. This language exhibits different forms to express the deontic and epistemic modalities and also to mark a context as realis or irrealis. The main goal of this article is to describe two markers of deontic modality in Paresi: maika and wa(iye)hena ${ }^{1}$ and investigate their relationship with the mood category realis vs irrealis.

There are few studies on modality in this language; as far as we know, there is only the work of Rech and Brandão (2018) on the maika deontic particle. Our research aims to contribute to the description of deontics in Paresi, showing that wa(iye)hena also constitutes a deontic particle, used to indicate both possibility and necessity, similar to maika. In this article, our focus is the investigation of the contexts of deontic necessity, from which we present a preliminary analysis of the particles maika and wa(iye)hena, relating them to the two types of obligations that are in Feldman (1986): ought-to-do and ought-to-be. For the data collection, we used mainly two questionnaires on deontics, which were applied to three native speakers of the Paresi language, as well as texts data that integrate a language database. $^{2}$ Our theoretical framework is based on the following authors: Feldman (1986), Mithun (1995, 1999), Palmer (2001), and Hacquard (2006, 2010).

In the next section, we provide a brief theoretical overview of the categories of mood and modality, presenting the two types of obligations (ought-to-do and ought-to-be) from Feldman (1986), important properties of the realis/irrealis category in some languages (Mithun 1995, 1999, Silva 2013, Brandão 2014), and some more recent works on deontic modality (Hacquard 2006, 2010; Rech \& Brandão 2018; Rech \& Varaschin 2017, 2018). In section 3, we present the methodology used in the research, which was based on Matthewson (2004). In section 4, we analyze the contexts where maika and wa(iye)hena are used and their relation to the category of realis vs irrealis. Finally, we systematized the contributions of this study to the description of Paresi.

\section{Mood and modality}

This research investigates the relation between realis/irrealis mood and deontic modality in Paresi. According to Palmer (2001), mood is described in terms of grammatical

\footnotetext{
${ }^{1}$ There are two variants for the same morpheme, one is wahena and the other is waiyehena, which are used by different speakers.

${ }^{2}$ The database contains data collected during research conducted by one of the authors from 2006 to 2014. The questionnaires were collected with consultants of the project "Deontic mode and the control feature in Portuguese and Paresi" of the Federal University of Pará (Portaria 012/2016).
} 
markers of realis and irrealis (in Native American and Papua New Guinea languages), or indicative and subjunctive (as it is treated in the study of European languages), whereas modality is related to the status of the proposition that describes the event (Palmer 2001). The two main categories are the deontic modalities, characterized by obligation and permission (Lyons 1977; Palmer 2001), and epistemic, relative to the speaker's knowledge of a proposition (Palmer 2001).

As far as we know, there is a little grammatical description about the categories of mood and modality in Paresi. Brandão (2014) presents the iya morpheme as an irrealis marker and the ala and kala particles as indicators of epistemic modality. Rech and Brandão (2018) show the maika particle as a marker of deontic modality. In this article, we argue that Paresi presents two distinct markers to indicate deontic modality (maika and wa(iye)hena) and that the choice by either form is related to the type of obligations associated with the event: maika figures in contexts in which obligation falls directly on a participant; while wa(iye)hena figures in constructions that describe general laws or rules, without the responsibility of a participant for its realization. As in other languages, such as Jamul Diegueño, we suppose that Paresi order/obligation contexts are marked as realis or irrealis depending on the speaker's expectation of the realization of the event. An interesting aspect of Paresi, a language with rich morphology, is precisely to show the close relationship between mood (realis and irrealis) and the different particles of obligation (maika and wa(iye)hena).

The distribution of the deontic modality markers in Paresi seems to be related to the two types of obligations assumed by Feldman (1986) and identified as ought-to-do and ought-to-be. The first involves a relation between an event and a participant; and the second is characterized by expressing how a state of affairs should be, not directly responsible to any participant for ensuring the eventuality described. In (1) and (2), we transcribe examples of Feldman that illustrate these two types of obligations:

\section{(1) The legislature ought to prohibit loud motorcycles.}

(2) There ought to be a law against such things.

The sentence in (1) illustrates the type of ought-to-do obligation since it relates to the event (prohibiting noisy motorcycles) to an explicitly mentioned agent (the set of legislators). The sentence in (2) is associated with the ought-to-be interpretation, since it involves a property of a state of affairs that must occur, without the responsibility for this state of affairs falling on a particular participant. The study of the differences between maika and wa(iye)hena in Paresi was based mainly on the analysis of data resulting from the application of two experimental tasks - Questionnaire for elicitation of deontics present tense (Rech; Guesser; Lanes 2017) and Questionnaire for elicitation of deontics - past tense (Rech \& Brandão 2018b). In (3) and (4), we transcribe two contexts of deontic necessity that integrate the Questionnaire for elicitation of deontics - present tense applied to Paresi speakers:

(3) "Julia went to the hospital to visit her sister who is hospitalized for a transplant. Reporting that she was the patient's sister, the hospital receptionist allowed Julia to go to 
her sister's room outside of visiting hours. When handing a badge to Julia, the receptionist says: You should wear this badge for the duration of the visit. "

(4) "Pedro is a 17-year-old non-indigenous youth, who will turn 18 some days before the date of the first round of the next election. According to the Brazilian electoral code, Pedro must vote in the next elections."

In the context in (3), the receptionist gives an order directly to Julia, who is responsible for its realization. It is, therefore, an ought-to-do type obligation in Feldman's description. Context (4) illustrates a situation in which there is a law that applies to all non-indigenous individuals aged 18 or over; their default results in penalties. This context characterizes an obligation of the ought-to-be type since this law was not created in particular for Pedro, quoted in the context, but it applies to every participant who, like Pedro, is in the determined condition by law. For obligatory contexts of the ought-to-do type, as illustrated in (3), Paresi speakers used maika without the marking of irrealis. Whereas for the context described in (4), there was the use of wa(iye)hena with the morpheme iya. We then transcribe two data that correspond to sentences given by Paresi speakers in the translation task of the highlighted sentences in context (3) and (4) above. ${ }^{3}$

(5) Maika eze cracha ha=moka hi=hiye ha=wena-ne kitxiya

DEO DEM badge $2 \mathrm{sG}=$ put $2 \mathrm{SG}=\mathrm{BEN} 2 \mathrm{SG}=$ life-POSS until

'You must use this badge during your visit'4

(6) Hatyotare-ki iya wahena Pedro $\varnothing=$ haikoa-heta
next-time IRR DEO Pedro $3 \mathrm{SG}=$ come.back-PFV
(Next time, Pedro must vote)
'Pedro must vote next time (next election)'

In addition to the correspondence between the two types of obligations, pointed out by Feldman (1986) - ought-do-do and ought-to-be -, and maika and wa(iye)hena forms, which need to be better investigated in Paresi, this language shows that the same construction (deontic) is marked differently in relation to the realis/irrealis mood.

In the next subsection, we briefly approach the notion of realis/irrealis and show how this marking is done in Central Pomo, which displays distinct markers for realis and irrealis. We also present examples of realis/irrealis markings in the Jamul Diegueño language and also in Paresi, both of which display marking only for the irrealis mood; realis is the unmarked form in these languages.

${ }^{3}$ The abbreviations used in this paper are: 2 Second person, 3 Third person, ATR Attributive, BEN Benefactive, CAus Causative, COND Conditional, DEM Demonstrative, DEO Deontic, DIFF Different event, EMPH Emphasis, FUT Future, IFV Imperfective, IND Indicative, IRR Irrealis, LOC Locative, M Masculine, NEG Negation, NPOss Non-possessed, NR Nominalizer, o Object, PFV Perfective, PL Plural, Poss Possessed, PST Past, PURP Purpose, REAL Realis, RECP Reciprocal, RFL Reflexive, SEQ Sequential, SG Singular, SFV Semelfactive, sour Source, TH Thematic suffix, TRS (Aspect) Transitional, vM Middle voice.

${ }^{4}$ In sentence (5) we have the word wena 'life' as a translation for 'visit' '; in (6), the word haikoa 'come back' is used as a translation for 'vote'. 
2.1. Realis and irrealis mood

The marking of realis and irrealis is considered by some authors (such as Mithun 1995; Palmer 2001) as a modal category. Authors like Elliott (2000) and Michael (2014) consider it as a separate category, called the reality status system, which is defined as a grammatical category with the binary distinction of realis and irrealis. In this paper, we follow the work by Mithun, considering the realis and irrealis marking as a mood category because, as pointed out by Exter (2012), there are the theoretical difficulties with the concept of 'reality status': it is not defined systematically and the large cross-linguistic differences in the semantics of 'irrealis' are left unexplained.

Mithun (1995) associates the realis mood with factual situations or what is happening at the moment of speech. The characteristic contexts that present realis mood marking are those that appear in past and present tenses in the indicative mood. According to the author, the irrealis mood portrays situations in the world of thought, such as plans, goals, dreams or hypothetical events. The realis/irrealis mood are usually marked by particles, clitics, and inflectional morphemes. The following example illustrates the realis mood (7) and irrealis (8) markings in the Central Pomo language (Mithun 1995: 370-373):

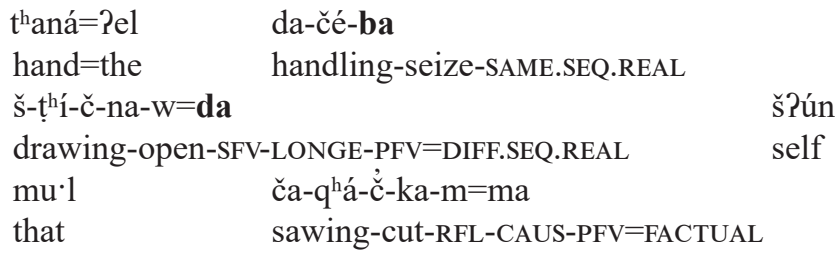

'When they grabbed his hand and pulled it (a knife) out, he cut himself.' (Mithun 1995: 373)

(8)

$\begin{array}{lll}\begin{array}{l}\text { cá-w=htow } \\ \text { house-LOC=from }\end{array} & \begin{array}{l}\text { Pé } y=\text { yo-hi } \\ \text { away=go-SAME.IRR }\end{array} \\ \begin{array}{ll}\text { da-čé=?le } & \text { táwhal } \\ \text { handling-catch=COND } & \text { work }\end{array} \\ \text { 'He should leave home and get a job' (Mithun 1995: 370) }\end{array}$

The event described in (7) occurs at a time earlier than the speech time. The marking with $b a$ or $d a$ particles - indicators of the realis mood - is expected, since events located in the past tense are realis because they have already occurred. The example (8) illustrates a context of irrealis, evidenced by the use of the $h i$ particle in a deontic construction, according to Mithun, - similar to what is seen in Paresi, in which iya (irrealis mood) appears with wahena (deontic).

Contexts of irrealis marking in languages are varied and are often influenced by culture. There are prototypically irrealis contexts, such as counterfactual, hypothetical, and conditional constructions. Others contexts can be marked as realis or irrealis depending on the language, such as the contexts of obligation, denial, interrogation, future tense, imperative. It is possible, even, that the same context is marked as realis and irrealis, depending on factors such as, for example, the speaker's expectation of (non)realization 
of the event in contexts of constructions in the future or imperatives. Examples (9) and (10), below, show that imperative constructions can receive marking of realis or irrealis in Jamul Diegueño (Mithun 1999: 179):

(9) k-naw

2sG-run

'Run!' (Mithun 1999: 179)
nya-m-mápa-pu
m-rar-x-s
IND-2sG-NM.want-DEM
2SG-do-IRR-EMPH
'Do whatever you want' (Mithun 1999: 179)

This language presents two types of imperative constructions: a strong imperative, associated with the realis mood in (9); and another polished one, which exhibits the irrealis marker $-x$ in (10). An imperative construction can be characterized as a command to the interlocutor; in this sense, the realization or not of the event is conditioned to the realization of the order expressed in the statement. The marking of this context as realis - which constitutes the unmarked form in Jamul Diegueño, according to (9) -, suggests the speaker's certainty in relation to the realization of the order and, consequently, to the accomplishment of the event. The marking of this context as irrealis, by the use of the $-x$ marker in (10), expresses politeness, signaling a suggestion; therefore, there is no certainty on the part of the speaker regarding the accomplishment of the event.

We now present some constructions marked with realis or irrealis mood in Paresi. Previous works on this topic are Silva (2013), and Brandão (2014). Silva (2013: 364) affirms that there is the marking of realis and irrealis in Paresi, and that this integrates the mood category. This author presents the following morphemes as indicators of the irrealis mood: iya 'conditional', zakore 'conditional counterfactual', ira 'jussive', kala 'potential' and motya 'hypothetical'. Brandão (2014) considers the markings realis/irrealis as a separate system: the realis mood corresponds to the unmarked form, while the irrealis is marked by the iya morpheme.

The contexts that receive the irrealis marking in Paresi, pointed out by Brandão (2014), are the following: negation in the future and conditional constructions, as illustrated respectively by examples (11) and (12):
(11) mama ene ne-hena: "maiha iya hi=yane-ta!" mother PST Say-TRS NEG IRR 2SG=go-IFV
'My mother said: "You will not go!"' (Brandão 2014: 355)
(12) no=zane-heta iya hoka Onizokae $\varnothing=$ amaikohare $1 \mathrm{SG}=$ go-PFV IRR CON Onizokae $3 \mathrm{sG}=$ be.sad 'If I go away, Onizokae will get sad' (Brandão 2014: 394)

Example (11) presents a prohibitive construction or also called a negative imperative. The iya is used with the negation maiha to indicate a more polished imperative, used as an advice; the strong imperative, in turn, is expressed only through the negation awa. This 
marking resembles that of the Jamul Diegueño language (see (9) and (10)). Regarding example (12), iya is used in the conditional sentence (called protasis), which introduces a hypothetical situation.

\subsection{Deontic modality}

The distinction between the two types of obligations (ought-to-do and ought-to-be), presented by Feldman (1986), is taken up by Brennan (1993), and Hacquard (2006, 2010), who approach the subject from a syntactic-semantic perspective. These authors relate the ought-to-do deontics to the event described by the VP. Thus, the obligation would be directed to one of the participants of this event, and usually, it falls on the subject of the sentence. On the other hand, the ought-to-be deontic is associated with the speech event, and the obligation may fall on one of its participants, usually the addressee (Hacquard 2006, 2010); ${ }^{5}$ at this point, such a concept differs from Feldman (1986), for whom the obligation of the ought-to-be type does not fall directly on any individual.

Rech and Varaschin $(2017,2018)$ investigated these two types of obligations in Brazilian Portuguese (BP). According to the authors, this distinction is manifested in BP and is related to the (non-)occurrence of an agentive participant [+ $\mathrm{Ag}]$ in the event described by the VP. The presence of a participant $[+\mathrm{Ag}]$ in the VP domain licenses the interpretation of the ought-to-do type to the deontic one. However, if there is no participant carrying this feature in the event described by the VP - for instance in constructions with unaccusative predicates that do not describe movement in space (Rech \& Varaschin 2017) and with statives [-control] (Rech \& Varaschin 2018) - only the ought-to-be interpretation will be made available to the deontic.

In a study on deontic modality in Paresi, Rech and Brandão (2018: 2823) present maika as a particle used to indicate both deontic necessity and possibility, as shown in sentences (13) and (14) below:

(13) Context: Diana likes to eat chocolate all the time when she is on vacation. Then, Marina, Diana's mother, before going to work, gives the following instruction to the nanny:

$\begin{array}{llllll}\text { maika } & \text { makani } & \text { weta taita } & \text { chocolate } & \text { Diana ana } & \mathrm{h}=\mathrm{itsa} \\ \mathrm{DEO}_{\text {Obligation }} & \text { tomorrow } & \text { early only } & \text { chocolate } & \text { Diana BEN } & 2 \mathrm{sG}=\text { give }\end{array}$

'You must give chocolate to Diana only early in the morning' (Rech \& Brandão 2018: 2823).

$$
\begin{aligned}
& \text { Paula, maika } \mathrm{h}=\text { ehokoty-oa } \\
& \text { Paula } \quad \mathrm{DEO}_{\text {Permission }} \quad 2 \mathrm{SG}=\text { lie.down-VM } \\
& \text { 'Paula, you can lay down' (Rech \& Brandão 2018: 2823). }
\end{aligned}
$$

${ }^{5}$ I believe that there is a fundamental distinction between these two types of deontics. Ought-to-do deontics are the kind captured in Kratzer's system via a circumstantial modal base (which picks out facts of the base world) and a deontic ordering source. Ought-to-be deontics, on the other hand, seem to double a modal statement with a performative act, namely, that of putting an obligation on the addressee. (Hacquard 2006: 41). 
In both examples, maika figures with second-person proclitic $(h=)$, which corresponds to the subject of the sentence, on which is given the order in (13) and the permission in (14).

In this research, we argue that there are two markings of deontic modality in Paresi: besides maika, already pointed out by Rech and Brandão (2018), there is also a wa(iye) hena particle. Like maika, wa(iye)hena is also used to indicate deontic possibility and necessity, as illustrated respectively in sentences (15a) and (15b):

$\begin{array}{cccccc}\text { a. Galego } & \text { iya } & \text { waiyehena } & \varnothing=\text { zawa-tya } & \text { haira } & \text { kapo-koa } \\ \text { Galego } & \text { IRR } & \text { DEO }_{\text {Permission }} & 3 \mathrm{SG}=\text { throw-TH } & \text { ball } & \text { field-LOC }\end{array}$

(Galego, he can play soccer in the field)

'Galego can play soccer in the field'

$\begin{array}{lllll}\text { b. Hatyotare-ki } & \text { iya } & \text { wahena } & \text { Pedro } & \varnothing=\text { haikoa-heta } \\ \text { next-time } & \text { IRR } & \text { DEO }_{\text {Obligation }} & \text { Pedro } & 3 \mathrm{SG}=\text { come.back-PFV }\end{array}$

(Next time, Pedro must vote)

'Pedro must vote next time (next election)'

The sentences in (15) show topicalized constituents. Following the analysis of Rizzi (1997), it is assumed that the topic fills the position of specifier of the category TopP, in the left periphery of the sentence, and it can involve a resumptive clitic. The topic is, therefore, a preposed element, characteristically highlighted in the speech by a "comma intonation". From the pragmatic point of view, it expresses known information, somehow available and salient in the previous discourse; in the case of the sentences in (15), the contexts of the deontic elicitation questionnaires. Speakers use the topicalization feature to highlight and emphasize the syntagma chosen as the main one according to the context outlined above.

The presence of a topicalized constituent seems to be characteristic of structures with wa(iye)hena, as we will discuss later in this paper. In (15a), the permission expressed by the particle waiyehena falls on the subject of the sentence Galego, which is a topicalized element, correferenced by a third-person proclitic $(\varnothing)$, an unmarked form in Paresi. In (15b), there is also topicalization of a constituent - the adjunct Hatyotareki 'next time'. In this sentence, wahena indicates a deontic necessity - expressing obligation, which falls on the subject of the sentence (Pedro).

The use of the maika and wa(iye)hena particles shows that Paresi marks in the lexicon the type of modality but not the modal force. At this point, it differs from languages like $\mathrm{BP}$, where the modal auxiliaries pode (can) and deve (must) express both epistemic and deontic modality; in relation to the modal force, pode corresponds to a deontic indicating only possibility, whereas the deontic deve indicates only necessity. According to Rullmann et al. (2008), the inverse relationship between the specification of the type of modality and the modal force is a trend in natural languages. 
3. Methodology

Regarding methodological support, we used controlled elicitation tests with the translation task (Matthewson 2004). To understand deontic modality indicator items from the formal perspective, two questionnaires were elaborated: (i) Questionnaire for elicitation of deontics: present tense (Rech et al. 2017) and (ii) Questionnaire for elicitation of deontics: past tense (Rech \& Brandão 2018). Both questionnaires were elaborated in Portuguese and applied to Paresi speakers who are bilingual in BP. These questionnaires were based on the Modal Questionnaire for Cross-Linguistic Use (Vander Klok 2014). ${ }^{6}$ A new version of the Vander Klok's Questionnaire was necessary to adapt the contexts to the Paresi culture, in order to minimize possible difficulties with vocabulary or due to cultural differences.

These questionnaires present contexts of deontic necessity and possibility. The sentences for which the translation task is required are inserted in a context with information about where the law or rule is or from who is the order or permission and who is involved. Besides the translation task, there is a question about whether there are other ways in Paresi to express this same content (See Appendix I and II). Examples (16) and (17) integrate the experimental task and correspond to contexts of deontic possibility and necessity, respectively:

(16) Context of deontic possibility:

Context: "The soccer field is only for children under 15 years old. Galego is 11 years old. It is not obligatory that he goes to the field if he does not want, but Galego can play soccer in the field".

(17) Context of deontic necessity:

Context: "According to article 244 of the Brazilian Traffic Code, when you ride a motorcycle, you have to wear a helmet"

The first questionnaire (the present tense one) presents four contexts of possibility and six contexts of deontic necessity. Of the latter, two contexts are associated with the concept of ought-to-do obligation; and four contexts, to the ought-to-be type (cf. Feldman 1986). This questionnaire was applied to three Paresi speakers (JZ, JQ, and $\mathrm{MF}^{7}$ ). The second questionnaire (the past tense one) presents four contexts of possibility and four contexts of deontic necessity. Of this latter, one context is associated with the ought-to-do obligation; and three contexts, with ought-to-be obligation. This last questionnaire was applied to two speakers (JQ and MF).

In section 4, we present some morphosyntactic properties of the particles indicating deontic possibility and necessity in Paresi (maika and wa(iye)hena) and, in the sequence, we show how they relate to the category of realis/irrealis mood.

${ }^{6}$ The Modal Questionnaire for CrossLinguistic Use (Vander Klok 2014) is avaiable on the website $<$ https:// www.eva.mpg.de/lingua/tools-at-lingboard/questionnaire/cross-linguistic-use.php>. Accessed on Jun. 2017.

${ }^{7}$ The speakers were males, with ages between 40 and 50 years old, and bilinguals in Paresi and BP. They are teachers at the school in the community and two of them have a Bachelor's degree in Language. 


\section{Maika and Wa(iye)hena: relationship with the mood category (realis/irrealis)}

The notion of modality can be expressed through affixes or independent words, such as verbs, modal auxiliaries, particles or adverbs (van der Auwera and Ammann 2013; Cinque 1999, 2006). The deontic wa(iye)hena has particle properties, similar to maika, classified as particle by Rech and Brandão (2018). Particles are functional morphemes, phonologically independents, with no nominal or verbal morphology markings and with peculiar syntactic distribution (Zwicky 1985). The particles morphologically resemble the adverbs because they are invariant, but the two classes have different syntactic distributions.

The morpheme maika is invariable, similar to the adverbs, but unlike them, it does not have a free syntactic distribution (Brandão 2014; Rech \& Brandão 2018). Maika appears in a high position, according to (13), and it may be preceded only by a vocative element or discursive marker, as in (14). The syntactic distribution of maika is not characteristic of adverbs, which occupy different positions, appearing even at the end of the sentence. It seems to be the case that maika corresponds, in fact, to a particle (cf. Rech \& Brandão 2018), because it occurs on the left periphery of the sentence, similarly to other particles, which indicates tense and mood, such as ite 'future', ene 'past' and iya 'irrealis', that also occupy a high position (which is obligatorily the second position).

It is important to note that a high position for an ought-to-be deontic is not provided in Cinque's hierarchy, since that modal heads associated to permission and obligation reading are above the scope of tense and aspect categories. Cinque $(1999,2006)$ assumes that notions of mood, modality, tense and aspect are given by functional categories that make up the Middlefield (IP). These are rigidly ordered, forming a hierarchy of functional head, which, according to the author, is part of universal grammar, since it manifests itself through languages. Below, we give part of the Cinque's hierarchy to show the ordering of some important functional heads for this research:

\section{Hierarchy of functional projections:}

$$
\begin{aligned}
& \text { MoodP }_{\text {speech }} \text { act }>\text { MoodP }_{\text {evaluative }}>\text { MoodP }_{\text {evidential }}>\text { ModP }_{\text {epistemic }}>\operatorname{TP}(\text { Past })>\operatorname{TP}(\text { Future })>\ldots \\
& >\operatorname{ASpP}_{\text {habitual }}>\operatorname{ASpP}_{\text {repetitive(I) }}>\operatorname{ASpP}_{\text {frequentative(I) }}>\operatorname{ModPV}_{\text {olitional }} \operatorname{ASpP}_{\text {celerative(I) }}>\operatorname{TP}(\text { Anterior })> \\
& \mathrm{ASPP}_{\text {terminative }}>\mathrm{ASPP}_{\text {continuative }}>\mathrm{ASPP}_{\text {retrospective }} \mathrm{ASpP}_{\text {proximative }}>\mathrm{ASpP}_{\text {durative }}>\mathrm{ASP}_{\text {habitual }}>\mathrm{ASP}_{\text {delayed }}> \\
& \operatorname{ASpP}_{\text {predispositional }}>\operatorname{ASpP}_{\text {repetitive (I) }}>\operatorname{ASpP}_{\text {frequentative }}(\mathrm{I})>\operatorname{MOdP}_{\text {volition }}>\operatorname{ASpP}_{\text {celerative (I) }}>\operatorname{ASpP}_{\text {terminative }} \\
& >\operatorname{AspPc}_{\text {ontinuative }}>\mathrm{AspP}_{\text {perfect }}>\mathrm{AspP}_{\text {retrospective }}>\mathrm{AspP}_{\text {proximative }}>\mathrm{AspP}_{\text {durative }}>\mathrm{A} \mathrm{spP}_{\text {progressive }}> \\
& \mathrm{AspP}_{\text {prospective }}>\mathrm{AspP}_{\text {inceptive }}>\text { ModP }_{\text {obligation }}>\mathbf{M O d P}_{\text {ability }}>\mathrm{ASpP}_{\text {frustrative/success }}>\text { ModP }_{\text {permission }} \\
& >\operatorname{ASpP}_{\text {conative }}>\mathrm{ASpP}_{\text {completive (I) }}>\text { VoiceP }>\operatorname{ASpP}_{\text {celerative (II) }}>\operatorname{ASpP}_{\text {inceptive (II) }}>\operatorname{ASpP}_{\text {completive (II) }}>
\end{aligned}
$$

The functional head associated with the epistemic modality occupies a high position in this hierarchy, being located above the categories of tense and aspect; while heads associated to the notion of obligation, abilities, and permission occupy a low position, 
closer to the lexical or thematic domain of the sentence, that is, of $\mathrm{VP}^{8}$. As we show in section 2.2, Brennan (1993) and Hacquard $(2006,2010)$ present evidence in English for the existence of a deontic interpreted in a high position, similar to the modal epistemic head. Rech and Varaschin $(2017,2018)$ show evidence of this type of deontic in BP. In this article, we argue that the Paresi data also signal in the direction of the existence of a deontic interpreted in a high position.

The morpheme wa(iye)hena presents a syntactic distribution similar to that of the maika particle, also occupying a high position in the sentence. Wa(iye)hena can appear at the beginning of the sentence, as in example (18) below, or following a topicalized constituent and the irrealis morpheme, as in (19).
Waiyehena iya
Galego
$\varnothing=$ kitxiya-tya
DEO $_{\text {Permission }}$ IRR
Galego
$3 \mathrm{SG}=$ play.soccer- $\mathrm{TH}$

'Galego can play soccer'
(19) Galego iya waiyehena
Galego IRR DEO $_{\text {Permission }}$
(Galego, he can play soccer)
'Galego can play soccer'

\author{
$\varnothing=$ kitxiya-tya \\ $3 \mathrm{SG}=$ play.soccer- $\mathrm{TH}$
}

In (18), Waiyehena occurs in a higher position than the particle iya, whereas in (19), because there are a topicalized constituent and the morpheme iya, waiyehena takes place immediately after the irrealis morpheme. It is important to note that the topicalized constituent and the categories of irrealis and deontic modality occupy high positions in the sentence structure, always appearing above the element with the function of subject.

Maika and wa(iye)hena seem to differ, however, in relation to their occurrence in constructions with topicalized constituents. Of the 31 occurrences of wa(iye)hena that were analyzed in this study (considering questionnaires and texts), 19 occur with some topicalized constituent - subject, complement or adjunct. Example (20), below, illustrates the use of wahena in structure with topicalization of the constituent with the function of adjunct:

$\begin{array}{llll}\text { (20) hatyotare-ki iya wahena } & \text { Pedro } & \varnothing=\text { haikoa-heta } \\ \text { next-time } \quad \text { IRR } \text { DEO }_{\text {obligation }} & \text { Pedro } & \text { 3sG=come.back-PFV } \\ \text { (Next time, Pedro must vote) } & & \\ \text { 'Pedro must vote next time (next election)' }\end{array}$

In (20), wahena appears after hatyotareki, a constituent in the topic position, and also after the morpheme of irrealis iya, which always occupies the second position in the sentence.

${ }^{8}$ According to Cinque's proposal, the interpretation of a functional head is tied to a certain position in the sentence structure. In this sense, we have an indication of an important role of syntax in the interpretation of these categories. As it happens in the hierarchy given above, the type of modality is reflected transparently in the syntactic structure, since it is given from the place in which a functional head appears in the hierarchy. 
The maika particle appears predominantly in the first position (in 32 of 39 cases). Of the 39 occurrences of maika in the text data and the questionnaires, only three cases occurred in which this particle appears in construction with a topicalized constituent. It was observed, however, that maika can follow items with vocative function (see example (14) above) and also discourse markers (cf. example (21b) below), not necessarily occupying the first position of the sentence. Examples (21a) and (21b) respectively show maika occupying the first position and maika in constructions with a discursive element in the first position:

\begin{tabular}{|c|c|c|c|c|}
\hline a. maika $=$ ite & $\mathrm{za}=$ waiye & hotyali-ki-tsa & heko & zekohatse-ti-nae \\
\hline $\begin{array}{l}\mathrm{DEO}=\mathrm{FUT} \\
\mathrm{wa}=\mathrm{moka}\end{array}$ & $2 \mathrm{PL}=\operatorname{good}$ & group $=$ CAUS $-\mathrm{TH}$ & moment & leader $=$ NPOSS-PL \\
\hline $1 \mathrm{PL}=$ put & t & e moment & & \\
\hline
\end{tabular}

\begin{tabular}{|c|c|c|c|c|c|}
\hline \multirow{2}{*}{$\begin{array}{l}\text { b. Eaotseta } \\
\text { then }\end{array}$} & "maika & baba & Zatyamare & $\varnothing=$ aitse-hena & \multirow{3}{*}{$\begin{array}{l}\text { hotxika } \\
\text { pirapotanga }\end{array}$} \\
\hline & DEO & father & Zatyamare & $3 \mathrm{sG}=\mathrm{kill}=\mathrm{TRS}$ & \\
\hline$\varnothing=\mathrm{its}=\mathrm{er}$ & & no $=$ mani & $(\ldots)$ & $\varnothing=$ nea & \\
\hline $3 \mathrm{sG}=$ give & $=30$ & $1 \mathrm{SG}=\mathrm{BEN}$ & & $3 \mathrm{sG}=\mathrm{say}$ & \\
\hline
\end{tabular}

Note that the example (21a) shows the occurrence of maika above the future particle ite. According to Cinque $(1999,2006)$, tense categories (TPPast and TPFuture) occupy a high position in the Middle field (IP), appearing above all aspectual heads and almost all modal heads, with the exception of the modal epistemic head.

The occurrences of wa(iye)hena and maika in our data allow us to suppose that there is a close relationship between the type of obligation expressed by the wa(iye)hena particle and topicalized structures. Regarding the position of these particles in the sentence structure, it seems to be the case that both occupy a high position, appearing above the subject and below only of topicalized constituents, vocative and discourse markers categories of interface between syntax and discourse.

The data collected from the questionnaires point to the existence of two types of obligations in Paresi: one indicated by the maika particle; and another, by the particle wa(iye)hena. The first figures, preferably, in contexts in which a participant is directly responsible for the realization of the event and seems to be associated to the realis mood. On the other hand, wa(iye)hena is employed in contexts of laws and general rules, which describe how a state of affairs should be, and co-occurs predominantly with the morpheme iya (irrealis marker): of the 31 constructions with the wa(iye)hena, in 21 it figures with the morpheme iya.

In the sequence, we present the maika (subsection 4.1) and wa(iye)hena particles (subsection 4.2) as markers of deontic necessity in Paresi, showing their differences in relation to factors such as modal orientation, type of obligation and relation with the mood category of realis/irrealis. Finally, we address the few cases in which maika figures in irrealis contexts; and wa(iye)hena, in realis contexts (subsection 4.3). 


\subsection{Maika in realis contexts}

As described in Rech and Brandão (2018), maika occurs with the second and third persons in contexts of obligation and permission; as modal of obligation, the authors observed a preference for constructions in which maika figures with the second person. In this paper, we restrict ourselves to the analysis of maika in the context of obligation, that is, as a particle of deontic necessity, similar to the approach adopted for wa(iye)hena in subsection 4.2. ${ }^{9}$

In general, maika was used to indicate deontic necessity in realis contexts of the Questionnaire for elicitation of deontics: present tense, as in sentences (22) and (23) below, resulting from the translation task from BP to Paresi (see contexts in (3) and (17), respectively):

\begin{tabular}{|c|c|c|c|}
\hline Maika & eze & cracha & ha $=$ moka \\
\hline DEO & DEM & badge & $2 \mathrm{sG}=\mathrm{put}$ \\
\hline ha=wena-ne & & & \\
\hline $2 \mathrm{sG}=$ life-POSS & & & \\
\hline
\end{tabular}

$\begin{array}{lllll}\text { Maika } & \text { kaiyehi-ti-ni-tini } & \text { ha=moka } & \text { hi=kaiye } & \text { hiye } \\ \text { DEO } & \text { head-NPOSS-NR-? } & \text { 2sG-put } & 2 \mathrm{sG}=\text { head } & \text { BEN } \\ \text { 'You have to wear a helmet in your head' } & & \end{array}$

The sentence context (22) (described in (3)) presents an order given by the receptionist to the visitor of a hospital patient. It is characterized as an ought-to-do context because it is an order directed at an individual (the second person $h a=$ ), who becomes responsible for performing the event described in the sentence. The context referring to the sentence (23) refers to a law of the Brazilian Traffic Code that must be followed by all Brazilians when riding a motorcycle; therefore, it does not fall on any particular participant. The speaker, however, directs an order to the interlocutor (as evidenced by the second person marker $h a=$ ) so that the helmet is placed in a specific situation. When an agent is held accountable for performing the event (putting on the helmet), the notion of obligation employed in construction corresponds to that of the ought-to-do type (cf. Feldman 1986). It is important to note that the sentences of examples (22) and (23), where maika was used, corresponding to the realis mood (unmarked form in Paresi), as indicated by the absence of the iya morpheme. We assume that the use of the realis mood in these contexts is related to the speaker's expectation that the event becomes real since it makes a specific agent responsible for its realization.

\subsection{Wa(iye)hena in irrealis contexts}

We will turn to the analysis of the use of wa(iye)hena in irrealis contexts, in which the iya morpheme is used. The data from this research show a close relationship between this

${ }^{9}$ The main motivation to focus our analysis on the use of maika and wa(iye)hena as markers of deontic necessity was to establish a relationship between the distribution of these particles in Paresi and the description of the ought-to-do and ought- to-be deontics according to Feldman (1986). 
deontic particle and the irrealis mood since the iya morpheme occurs in most sentences with wa(iye)hena. The sentences in (24) and (25), below, illustrate this relation:

Context: "The social organization of some indigenous communities is hierarchical. In Enawene Nawe, there are a maximum leader and leaders of each clan. According to the culture of that community: The leaders should be chosen in a meeting."

\begin{tabular}{|c|c|c|c|}
\hline zekohatse-ti & iya & wahena & $\varnothing=\mathrm{ka}-\mathrm{zo}=\mathrm{mo}-\mathrm{ka}-\mathrm{ka}$ \\
\hline leader-NPOss & IRR & DEO & $3 \mathrm{SG}=\mathrm{ATR}-2 \mathrm{PL}=$ put-TH-NR \\
\hline irae-kakoa-ti & & heko & \\
\hline talk-RECP-NPOSS & & moment & \\
\hline (The leader, he $\mathrm{m}$ & & $\operatorname{sen}$ in a $m$ & ng) \\
\hline
\end{tabular}

In this case, the reference for the deontic interpretation is the culture of the Enawene Nawe community, according to which the leaders should be chosen in a meeting. The sentence to be translated into Paresi is inflected in the passive voice without the explicitness of the agent on which the obligation falls. The translation given by the speaker JQ, in (24), contains the wahena particle, the morpheme irrealis and the passive nominalizing morpheme $-k a{ }^{10}$ The structure chosen by the speaker in (24) highlights the constituent zekohatseti 'leader' (which is correferenced by the zero morpheme of the third person) through the use of the topicalization device, and provides information about how the process of choosing the leader occurs through lexicalization of the constituent iraekakoati heko (which literally means 'moment of reciprocal conversation'). The agent, on whom the obligation falls, is not overtly expressed (corresponds to the community members, who were at the meeting and have the power to choose the leader). Because it is not about a specific event for which a participant was responsible, but rather a likely event since it presents a general rule of the Enawene Nawe community (which determines how its leadership is chosen), the omission of the agent is expected. This example illustrates, therefore, the use of the wahena particle as a deontic of the oughtto-be type, as it figures in a sentence that describes how the state of affairs must be, and not the person who is responsible for it.

In the context of the production of the sentence (25), a rule of the Pedagogical Political Project of the schools of Paresi communities is described: that of teaching the Paresi language from kindergarten through high school. Next, we transcribe the context in full, followed by the sentence in Paresi given by the speaker JQ. This corresponds to the translation of the BP sentence highlighted in the context.

Context: "With the goal of revitalization, one of the initiatives was to add the teaching of the native language in the curriculum of the schools. The curriculum is planned by indigenous teachers and the leader. According to the curriculum: "The

${ }^{10}$ In Paresi, this suffix $-k a$ is used to derive nouns from verbs (Brandão 2014: 216). In (24), there is a nonverbal predicate construction where the nominalized form with -ka (zomoka-ka) is used with the attributive prefix $k a$ - in ka-zomoka-ka, meaning literally "he has his emplacement'. 
Paresi language must be taught at the school from elementary school through high school".

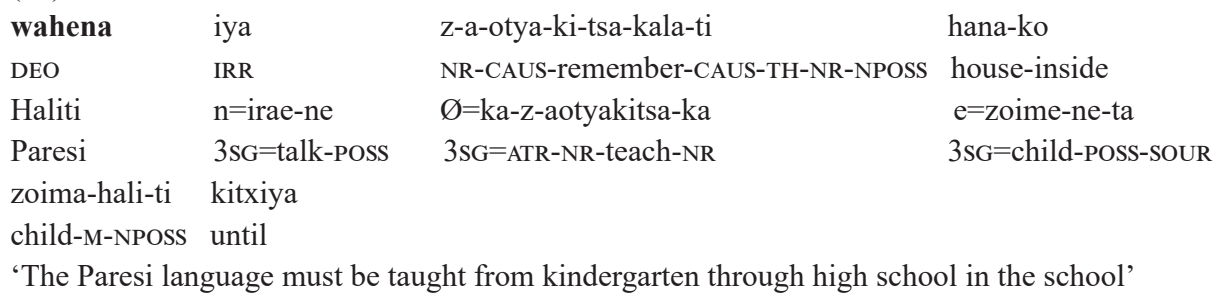

In this example, the speaker used the wahena particle in the first position, differently from the example (24), in which the topicalization device is used. Note also that there is no explicit indication of the individual responsible for the event described in the sentence, similarly to (24). It is possible to infer here that the obligation is oriented to an agentive participant not overtly expressed in the structure: all teachers who have had, have or will still have a link as schools of the Paresi community. Note that (25) exhibits the same structure in (24), with the passive nominalizing morpheme -ka: kazaotyakitsaka 'it is what must be taught'. The example (25) does not describe a delimited event in time, but rather how a state of affairs should be; then, here wahena is used as a deontic of the ought-to-be type.

As in (24), we can also observe here the occurrence of the irrealis marker iya, suggesting that the speaker has little or no expectation regarding the accomplishment of a specific event. In the example (25), the speaker chooses to lexicalize the constituents Haliti-Paresi niraene 'the language Paresi', zaotyakitsakalati hanako 'at school' and ezoimeneta, zoimahaliti, terms that refer to kindergarten and high school respectively, that are related to the event of teaching, following the sentence pattern in BP for which the translation task was requested. The difference between these examples seems to be in the use of the topicalization device, used only in (24), in which the speaker topicalizes the constituent zekohatseti 'leader', which is an old information given in the context of occurrence of the sentence (24). As mentioned in the article, there seems to be a close relationship between the use of the wahena particle and the topicalization device - this needs to be better investigated, which we will do in future research.

In conclusion, both of the sentences, (24) and (25), seem to express an ought-to-be obligation, insofar as they describe how a state of affairs should be, not directly making a participant responsible for the event, according to Feldmann (1986).

\subsection{Maika in irrealis contexts vs wa(iye)hena in realis contexts}

We find only one case of maika with the morpheme irrealis (iya). This data was elaborated in the same context of production of the sentence (25) above but produced by another consultant (Jz). It is important to note that the consultant JZ elaborated a sentence in the active voice, differing from the BP sentence for which the translation task was 
requested, which was in the passive voice without the agent's expression. We observe that in Paresi, there is no specific inflection marker to indicate passive voice, which could explain the insertion of a noun phrase with agentive properties in the subject's function in the sentence (26), produced by JZ:

Haliti-nae

person-PL

$\emptyset=$ a-otya-ki-tsa-ha

$3 \mathrm{SG}=$ CAUS-remember-CAUS-TH-PL

inityohali-ti

old.person-NR

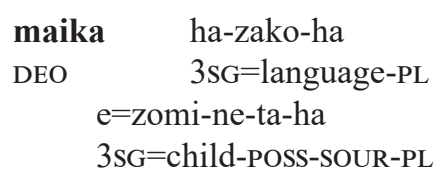

kitxiya

until

(The Paresi, they must teach their language from childhood through old age)

'The Paresi must teach their language from childhood through old age'

In this construction, the obligation expressed by maika falls on the noun phrase Paresi indigenous (Halitinae), which corresponds to the subject of the sentence. Surprisingly, this is the only case we find in our data - both the questionnaires and the text database (Brandão 2014) - in which maika appears with the iya morpheme, an indicator of irrealis. We assume that the use of irrealis in this construction may be related to the fact that the obligation does not fall on a specific agent (individual), but rather on the Paresi community of speakers, which affects control over the event and, consequently, interferes with the expectation of the speaker in relation to its realization.

In the data there were also cases where wa(iye)hena appeared in constructions without the irrealis morpheme. These correspond to sentences in the past tense, as (27), produced for the same context as sentences (25) and (26) above:

\begin{tabular}{|c|c|c|c|}
\hline Haliti & $\mathrm{n}=$ irae-ne & wahena & $\varnothing=$ ka-z-a-otya-ki-tsa-ka \\
\hline Paresi & $3 \mathrm{sG}=$ talk-POSS & DEO & $3 \mathrm{SG}=\mathrm{ATR}-\mathrm{NR}-\mathrm{remember}-\mathrm{NR}$ \\
\hline z-a-otya-ki-tsa-kala-ti & & hana-ko & hetati-ta \\
\hline NR-CAUS- remember-CA & AUS-TH-NR-NP & house-LOC & formerly-SOUR \\
\hline $\mathrm{e}=$ zoime-ne-ta & zoima-hali-t & & iya \\
\hline $3 \mathrm{sG}=$ child-POSS-SOUR & child-M-NPO & & \\
\hline
\end{tabular}

(The Paresi language, it had to be taught in the school, formerly, from childhood until adolescence)

'The Paresi language had to be taught in the school from childhood until adolescence formerly'

In this example, there was also a change in relation to the sentence to be translated. The presence of the phrase hetati (formerly) indicates that it is a description of an event in the past. According to Mithun (1995, 1999); Elliott (2000), among others, past tense is a realis context for describing events that actually occurred. Therefore, the absence of the iya morpheme in (27) is expected. The use of the deontic particle wahena in this case probably occurs because the obligation does not fall directly on a participant. This 
sentence is describing how a state of affairs should be in the past, not who was responsible for securing this state of affairs.

\section{Final considerations}

The main objective of this research was to contribute with the description about deontic modality in Paresi, since little is known about this theme in this language. Rech and Brandão (2018) described maika as a deontic modality particle. Our study identified another marker associated with the deontic modality (wa(iye)hena), which also has particle properties. We show that both maika and wa(iye)hena are used to express possibility and deontic necessity, which shows that Paresi is a language in which modal force is not marked in the lexicon.

We present evidence that maika and wa(iye)hena correspond to different types of obligations, differing in relation to factors such as on who falls in the order/obligation and on the expectation of the speaker in relation to the accomplishment of the event described in the sentence. The first factor is associated with the distinction between the types of obligations in Feldman (1986): ought-to-do and ought-to-be; and the second, to marking a context as realis or irrealis.

As for the morphosyntactic properties of maika and wa(iye)hena, we observe that they exhibit a particle behavior as they do not inflect and do not occupy the final position of the sentence, thus differentiating from the adverbs, which also do not undergo inflection but may appear in the last position of the sentence. Still, in relation to the position, the data that we analyzed indicate that both maika and wa(iye)hena occupy a position above temporal categories. They seem to follow only categories that interface with discourse, such as topicalized constituents. The data also indicate a relationship between topicalization and the type of obligation marked with the wa(iye)hena particle - 19 of the 34 occurrences of wa(iye)hena were in structures with topicalization, contrasting with maika - only 3 of 39 occurrences of maika have constituted topicalized. It is important to investigate in detail constructions with topicalization and marking of deontic modality to verify if, in fact, a specific type of obligation in Paresi can favor topicalization, as our data seem to point out.

Finally, we emphasize the importance of analyzing these same particles in contexts of deontic possibility in future works. Such contexts are expected to be marked as irrealis since they denote possibility; however, from what we have seen in the data, the particle that appears in irrealis constructions is wa(iye)hena, although maika is also employed in contexts of deontic possibility.

\section{References}

Brandão, Ana Paula (2014). A reference grammar of Paresi-Haliti (Arawak) (Tese de doutorado). Austin: University of Texas at Austin. https://repositories.lib.utexas.edu/handle/2152/24847

Brennan, Virginia (1993). Root and epistemic modal auxiliary verbs (Tese de doutorado). Amherst: University of Massachusetts. https://scholarworks.umass.edu/dissertations/AAI9316625 
Cinque, Guglielmo (1999). Adverbs and functional heads: a cross-linguistic perspective. New York: Oxford University Press.

Cinque, Guglielmo (2006). Restructuring and functional heads: the cartography of syntactic structures. New York: Oxford University Press.

Elliott, Jennifer (2000). Realis and irrealis: forms and concepts of the grammaticalisation of reality. Linguistic Typology 5: 55-90. doi: https://doi.org/10.1515/lity.2000.4.1.55

Exter, Mats (2012). Realis' and 'irrealis' in Wogeo: A valid category? Language Documentation \& Conservation Special Publication: Melanesian Languages on the Edge of Asia: Challenges for the 21st Century 5: 174190. Disponível em https://scholarspace.manoa.hawaii.edu/handle/10125/4564. Acesso em (15/05/2018).

Feldman, Fred (1986). Doing the best we can. An essay in informal deontic logic (Philosophical Studies Series in Philosophy 35). Dordrecht, Boston: D. Reidel Publishing Company.

Hacquard, Valentine (2010). On the event relativity of modal auxiliaries. Natural Language Semantics 18(1): 79-114. doi: 10.1007/s11050-010-9056-4

Hacquard, Valentine (2006). Aspects of modality (Tese de doutorado). Cambridge: Massachusetts Institute of Technology. http://hdl.handle.net/1721.1/37421

Lyons, John (1977). Semantic, vols. 1-2. Cambridge University Press.

Matthewson, Lisa (2004). On the methodology of semantic fieldwork. International Journal of American Linguistics 70 (4): 369-415. doi:10.1086/429207

Michael, Lev (2014). The Nanti reality status system: Implications for the typological validity of the realis/ irrealis contrast. Linguistic Typology 18 (2): 251-288. doi: https://doi.org/10.1515/lingty-2014-0011

Mithun, Marianne (1995). On the relativity of irrealis. In Joan Bybee; Suzanne Fleischman (eds.). Modality in grammar and discourse. Amsterdam: John Benjamins.

Mithun, Marianne (1999). The languages of native North America. New York: Cambridge University Press.

Palmer, Roland (2001). Mood and modality. Cambridge: Cambridge University Press.

Rech, Núbia; Brandão, Ana Paula (2018a). A marcação de modalidade deôntica no Paresi. Fórum Linguístico 15(1): 2816-2827.

Rech, Núbia; Brandão, Ana Paula (2018b). Questionário para elicitação de deônticos: tempo passado. Ms.

Rech, Núbia S. Ferreira; Guesser, Simone Lúcia; Lanes, Elder José (2017). Questionário para elicitação de deônticos: tempo presente. Ms.

Rech, Núbia; Varaschin, Giuseppe (2017). Predicados inacusativos e a modalidade deôntica. Revista Letras 96: 219-238.

Rech, Núbia; Varaschin, Giuseppe (2018). Predicados estativos e os tipos de deôntico: ought-to-do e ought-to-be. Cadernos de Estudos Linguísticos 60(1): 159-177. 
Rullman, Hotze; Matthewson, Lisa; Davis, Henry (2008). Modals as distributive indefinites. Natural Language Semantics 16: 317-357. doi: 10.1007/s11050-008-9036-0

Silva, Glauber (2013). Morfossintaxe da língua Paresi-Haliti (Tese de doutorado). Rio de Janeiro: Universidade Federal do Rio de Janeiro.

Van der Auwera, Johan; Ammann, Andreas (2013). Situational possibility. In: Dryer, Matthew; Haspelmath, Martin (eds.) The world atlas of Language structures online. Leipzig: Max Planck Institute for Evolutionary Anthropology. Disponível em http://wals.info/chapter/74 . Acesso em (20/05/2017).

Zwicky, Arnold (1985). Clitics and particles. Language 61(2): 283-305.

doi: $\underline{10.2307 / 414146}$ 
APPENDIX

\section{Questionnaire for elicitation of deontics I (present tense)}

Date: 12018

Consultant:

Researcher:

Translation task

Items investigated: deontic modality (possibility and necessity).

Topic 1 - How do the speakers express permission in this language?

Context 1 [deontic possibility]:

"The soccer field is only for children under 15 years old. Galego is 11 years old. It is not obligatory that he goes to the field if he does not want, but Galego can play soccer in the field".

1. How do you express in Paresi the idea of the sentence that is highlighted?

2. Do you have more than one way to express this content?

Context 2 [deontic possibility]:

"Maria is a history teacher who greatly admires the culture of the Paresi people. She wants her students to have the opportunity to learn more about this culture. She then asks the leaders, Justino and Nelsinho, to visit the village together with a small group of students. Nelsinho says to the teacher: You can visit our village with your students."

1. How do you express in Paresi the idea of the sentence that is highlighted?

2. Do you have more than one way to express this content?

Context 3 [deontic possibility]:

"Indigenous peoples have an idea that everything belongs to everyone. In this sense, they do not consider themselves owners of a land, but with the right of use to cultivate. This right is guaranteed by Law: The Paresi can use their land to plant."

1. How do you express in Paresi the idea of the sentence that is highlighted?

2. Do you have more than one way to express this content?

Context 4 [deontic possibility]:

"Under the rules of the preschool where Wallyson studies, only family members are allowed to pick up a child. Wallyson's mother is the one who picks him up at school every day. Exceptionally today, she asked her eldest son to pick up his brother in preschool because she would be late. Considering the rules of the place where Wallyson studies, Wallyson's brother can pick him up at school." 
1. How do you express in Paresi the idea of the sentence that is highlighted?

2. Do you have more than one way to express this content?

Topic 2 - How do the speakers express obligation in this language?

Context 1 [deontic necessity]:

"With the goal of revitalization, one of the initiatives was to add the teaching of the native language in the curriculum of the schools. The curriculum is planned by indigenous teachers and the leader. According to the curriculum: "The Paresi language must be taught at the school from elementary school through high school".

1. How do you express in Paresi the idea of the sentence that is highlighted?

2. Do you have more than one way to express this content?

Context 2 [deontic necessity]:

"In the Yanomami culture, it is common to form a mini-village from a single family. This is because according to the social organization of the community: daughters must build their houses near the parents' house."

1. How do you express in Paresi the idea of the sentence that is highlighted?

2. Do you have more than one way to express this content?

Context 3 [deontic necessity]:

"The social organization of some indigenous communities is hierarchical. In Enawene Nawe, there are a maximum leader and leaders of each clan. These positions constitute a system of multiple leadership within the community. According to the culture of that community: The leaders should be chosen in a meeting."

1. How do you express in Paresi the idea of the sentence that is highlighted?

2. Do you have more than one way to express this content?

Context 4 [deontic necessity]:

"Julia went to the hospital to visit her sister who is hospitalized for a transplant. Reporting that she was the patient's sister, the hospital receptionist allowed Julia to go to her sister's room outside of visiting hours. When handing a badge to Julia, the receptionist says: You should wear this badge for the duration of the visit.".

1. How do you express in Paresi the idea of the sentence that is highlighted?

2. Do you have more than one way to express this content?

Context 5 [deontic necessity]:

"According to article 244 of the Brazilian Traffic Code, when you ride a motorcycle, you have to wear a helmet". 
RECH, BRANDÃO, \& WIT - THE RELATIONSHIP BETWEEN IRREALIS MOOD...

1. How do you express in Paresi the idea of the sentence that is highlighted?

2. Do you have more than one way to express this content?

Context 6 [deontic necessity]:

"Pedro is a 17-year-old non-indigenous youth, who will turn 18 some days before the date of the first round of the next elections. According to the Brazilian electoral code, Pedro must vote in the next elections."

1. How do you express in Paresi the idea of the sentence that is highlighted?

2. Do you have more than one way to express this content?

\section{Questionnaire for elicitation of deontics II (past tense)}

Date: $/ 2018$

Consultant:

Researcher:

Translation task

Items investigated: deontic modality (possibility and necessity).

Topic 1 - How do the speakers express permission in the past?

Context 1 [deontic possibility]:

"Only students were allowed to play soccer on the school's field. John is not a student at the school, but he wanted to play soccer in this field along with the other boys in the soccer championship that took place last week. Then, João's mother asked the director for permission to play soccer at the school. The director authorized. Thus, João could play soccer in the field".

1. How do you express in Paresi the idea of the sentence that is highlighted?

2. Do you have more than one way to express this content?

Context 2 [deontic possibility]:

"Maria is a history teacher who greatly admires the culture of the Paresi people. In January, she wanted her students to have the opportunity to learn more about this culture. Then, she asked the Paresi leaders to visit the village together with a small group of students. The leaders gave permission: Then, she could visit the village with your students."

1. How do you express in Paresi the idea of the sentence that is highlighted?

2. Do you have more than one way to express this content?

Context 3 [deontic possibility]:

"Indigenous peoples have an idea that everything belongs to everyone. In this sense, they do not consider themselves owners of a land, but with the right of use to hunt, collect fruits 250

LIAMES 18(2): 229-252 - Campinas, Jul./Dez. - 2018 
and plant. Today, the Paresi can only use the land that is demarcated for them: formerly, the Paresi could use all the land their ancestor left for them."

1. How do you express in Paresi the idea of the sentence that is highlighted?

2. Do you have more than one way to express this content?

Context 4 [deontic possibility]:

"Last year, according to the rules of the preschool where Wallyson studied, only family members were allowed to pick up a child. Wallyson's mother was the one who picked him up at school every day. One day, she asked her eldest son to pick up his brother in preschool because she would be late. Considering the rules of the place where Wallyson studied, Wallyson's brother could pick him up at school."

1. How do you express in Paresi the idea of the sentence that is highlighted?

2. Do you have more than one way to express this content?

Topic 2 - How do the speakers express obligation in the past?

Context 1 [deontic necessity]:

"Formerly, in the Yanomami culture, it was common to form a mini-village from a single family. This was because according to the social organization of the community: daughters had to build their houses near the parents' house."

1. How do you express in Paresi the idea of the sentence that is highlighted?

2. Do you have more than one way to express this content?

Context 2 [deontic necessity]:

"The social organization of some indigenous communities is hierarchical. Formerly, in the Enawene Nawe, there were a maximum leader and leaders of each clan. These positions constituted a system of multiple leadership within the community. During that time, according to the culture of that community: The leaders had to be chosen in a meeting."

1. How do you express in Paresi the idea of the sentence that is highlighted?

2. Do you have more than one way to express this content?

Context 3 [deontic necessity]:

"In the last week, Julia went to the hospital to visit her sister who is hospitalized for a transplant. Reporting that she was the patient's sister, the hospital receptionist allowed Julia to go to her sister's room outside of visiting hours. Then the receptionist handed a badge to Julia, and said to her that She had to wear the badge for the duration of the visit.".

1. How do you express in Paresi the idea of the sentence that is highlighted? 
RECH, BRANDÃO, \& WIT - THE RELATIONSHIP BETWEEN IRREALIS MOOD...

2. Do you have more than one way to express this content?

Context 4 [deontic necessity]:

"Pedro is a non-indigenous young man, who turned 18 some days before the date of the first round of the last elections. In order to avoid problems with electoral justice, Pedro had to vote in the last elections."

1. How do you express in Paresi the idea of the sentence that is highlighted?

2. Do you have more than one way to express this content?

Recebido: 30/7/2018

Versão revista e corrigida: 20/10/2018

Aceito: 26/11/2018 